\title{
INVESTIGATION OF AN APPROPRIATE TECHNOLOGY FORECASTING PROCESS FOR SASOL FOR THE NEW ENERGY ERA
}

\author{
L. Ma and A. J. Buys \\ Department of Engineering and Technology Management \\ University of Pretoria \\ leo.ma@,sasol.com, ajbuys@up.ac.za
}

\begin{abstract}
Sasol is predominantly an energy-based company. The energy industry is undergoing a fundamental transformation that may have a profound impact on Sasol's overall business. This study has been carried out to investigate the need to establish an appropriate technology forecasting process for the new energy era. Although there exist some evidence of technology forecasting within Sasol, they are scattered and unsophisticated. Technology forecasting as a tool enables managers to make better decisions and encourages networking and knowledge sharing within the organization, an important trait of a 'Learning Organization'. A theoretical framework of technology forecasting for Sasol is thereby formulated.
\end{abstract}

\section{OPSOMMING}

Sasol is hoofsaaklik ' $n$ energie-gebaseerde maatskappy. Die energie-industrie ondergaan tans 'n diepgaande transformasie wat 'n wesenlike impak kan hê op Sasol se totale besigheid. Hierdie studie is uitgevoer om die behoefte vir 'n toepaslike tegnologie-vooruitskattingsproses vir die nuwe energie-era te bepaal. Alhoewel daar bewyse bestaan vir tegnologievooruitskatting binne Sasol, is dit verspreid en ongesofistikeerd. Tegnologie-vooruitskatting is ' $n$ gereedskapstuk wat bestuurders in staat stel om beter besluite te neem en bevorder die gebruik van netwerke en kennis-uitruiling binne die organisasie, 'n belangrike eienskap van 'n 'Lerende Organisasie'. 'n Teoretiese raamwerk vir tegnologie-vooruitskatting vir Sasol word sodoende geformuleer. 


\section{BACKGROUND}

\section{End of the Oil Age?}

In the late 1990s, a steady stream of gloom and doom about the future of oil as energy source filled the popular media and science journals. The pessimists' argument is hinged on the premises that firstly the oil reserve is a finite resource - "one barrel extracted is one barrel less"; secondly the production of oil will decline when half of the world's oil has been consumed; thirdly, because the reserve is finite the future price of oil is depicted as an inclining curve, rising as the flow of oil slows and oil becomes more expensive to extract from underground. Contrarily, Adelman [1] argues that the notion of considering energy sources as finite in economic analysis should be questioned. It is price that is the indicator of scarcity, and "to explain the price of oil, we must discard all assumptions of a fixed reserve and an inevitable long-run rise." Therefore if the cost of developing and extracting reserves is less than the price of oil, companies will continue to invest in new reserves, and the cost of developing new oil reserves will decline. The logic progresses that when the prospect of scarcity, and the accompanying steady price hikes, begins to appear on the horizon, investment will be diverted to alternatives such as tar sand, shale and methanol, or new energy sources.

History demonstrates that the substitutions of prime energy sources have seldom been the direct consequence of resource scarcity. New energy sources often have other advantages than their predecessors such as higher energy content, lower cost of exploration and production, and convenience of transportation. Oil has replaced or is capable of replacing coal in virtually all industries where coal was once the only viable energy source, despite the fact that coal is the most abundant fossil fuel.

Technology development in engines, new materials and alternative energy sources, may render the debate on whether or not the world is running out of oil irrelevant. The internal combustion engine technology has advanced significantly since its early days, notably in fuel economy. Fuel economy of passenger cars in the USA has improved by 100 percent since the 1970s oil crisis - from 12 to 24 miles per gallon. Using new material like aluminium, composite material and carbon fibre, cars and trucks are becoming lighter and less thirsty for fuel. In April 2002, Volkswagen demonstrated what technology could achieve by building the first passenger car capable of doing $100 \mathrm{~km}$ with less than one litre of diesel. The entire car weighs a slim $290 \mathrm{~kg}$ by using novel materials.

Non-conventional types of fuel such as Compressed Natural Gas and Liquefied Petroleum Gas are fast being adopted in the transportation industry. The fuel cell is emerging as an important twenty-first century energy medium, which can utilise a wide range of fuels, from hydrogen and methanol to gasoline.

Are we at the doorstep of a new energy era, an industrial evolution commenced twenty-nine years ago by the OPEC oil crisis that is likely to become a revolution? 


\section{Sasol}

Since its establishment in 1950 with the original purpose to provide South Africa an affordable and reliable fuel supply, Sasol has undergone fundamental changes. Sasol today manufactures more than 200 types of fuel and chemical products at its production facilities in Sasolburg and Secunda as well as in Europe, the Middle East, Asia and North America. Its products are exported to more than 90 countries around the world. Amongst all its business activities, one venture remains largely unchanged - the diesel and gasoline business. Sasol today is still a predominantly energy-oriented company. For the 2001 financial year, production and sale of transportation fuel contribute to about 50 percent of the group revenue and 84 percent of the operating profit.

Sasol currently supplies $41 \%$ of South Africa's liquid fuel requirements and, as a result of its activities, the South African economy benefits substantially. But the energy industry will not exist in today's form for long. Sheikh Ahmed Zaki Yamani [2], Saudi Oil Minister from 1962 to 1986 , believes that oil prices are destined to crash in the long term and the world will never use up the last drop of oil, because it does not need to, "The Stone Age did not come to an end because we had a lack of stones, and the oil age will not come to an end because we have a lack of oil".

If an unexpected yet not improbable event such as a technology breakthrough in fuel cells disrupts Sasol energy business, it could possibly destabilize Sasol's entire business portfolio, because Sasol's chemical business would be inevitably affected by changes taking place in the energy business. If the diesel and gasoline businesses are wiped out, it is likely that the company Sasol, as we know it today, will also be wiped out. An increasingly unstable operating environment raises the need for some clues or early warning system that enables strategic adjustment to be made well in advance. Hence an appropriate framework of technology forecasting for Sasol's energy business must be in place. Not only must it forecast technological change in Sasol's own business (e.g. fuels), but also in related industries (automotive industry). It should be a key input into the process in which corporate strategy, business strategies and technology strategies are formulated.

The research question is this: Does Sasol have an effective technology forecasting system able to detect and address changes timely in the energy industry?

\section{THEORETICAL FRAMEWORK}

Pearce and Robinson [3] categorize the external environment of a business into the remote environment, the industry environment and the operating environment.

The technology dimension is one of the factors that constitute the remote environment, in which organizations, industries and nations operate. Forces in the remote environment are so dynamic and interactive that the impact of any single element cannot be wholly disassociated from the impacts of other elements. A firm must be aware of technological changes that might influence its industry. A technological breakthrough can have sudden and dramatic effects on a firm's environment. Twiss [4] specifies that the field of technology forecasting has to be very extensive if some important indications are not to be missed and it must include a wide range of social, economic, and political as well as technological factors. "However 
daunting the difficulties may appear, the manager cannot avoid making decisions which will be proved good or bad by the future. He must take a view of the future".

Porter [5] defines five forces that shape industrial competition as: 1) threat of entry; 2) powerful suppliers; 3) powerful buyers; 4) substitute products and 5) jockeying for position. Rivalry among existing competitors comes in many forms. Porter [6] recognizes the power of technology as a competitive variable that has the ability to alter competition through changing industry structure and competitive rules. Technological change can nullify the advantages of incumbents and create opportunities for newcomers and followers; and most important, technology change should be studied for its potential impact on industry structure.

\section{Technology Forecasting}

Pearce and Robinson [3] define technology forecasting as "the science to foresee both the existing technological advances and the probable future advances that can affect their products and services, and estimate their impact on an organization's operation." Twiss [4], sees that technology forecasting serves corporate strategy formulation by: 1) redefining the industry or the company's business objectives in the light of new technological competition; 2) modifying the corporate strategy and R\&D strategy and 3) improving operational decision making.

Regardless of the various definitions of technology forecasting, the complexity of technology forecasting requires a great deal of effort, time and resources. And the outcome may still have a high degree of uncertainty, as illustrated by the former chairman of IBM, Thomas Watson's statement "I think there is a world market for maybe five computers." Twiss [4] cautions that we should have a realistic expectation of the outcomes of technology forecasting, "If forecasting techniques can enable the manager to obtain a more accurate picture of the future and in consequence improve his decision making, the effort devoted to it is justified. This can be the only real justification for forecasting".

Forecasting is part of strategic management, a process that involves all levels of the firm to interact. Forecasting results in better decisions because group interaction generates a greater variety of strategies and because forecasts based on the specialized perspectives of group members improve the screening of options. Gaps and overlaps in activities among individuals and groups are reduced as participation in strategy formulation clarifies differences in roles. Resistance to change is reduced. The participants' greater awareness of the parameters that limit the available options makes them more likely to accept those decisions.

Business is shifting from one dominated by capital to one dominated by learning. De Geus [7] emphasizes in the Living Company that only living entities learn, and like all living systems, companies too must continue to learn in order to continue to live. A 'living company' depends on its institutional memory and its ability to anticipate the future. According to Brenneman [8], enduring companies excel at learning, anticipating the future, and accommodating it through changes. 


\section{Technology Forecasting Techniques}

According to Porter [9], specific techniques of technology forecasting fall into two main categories, exploratory and normative. Exploratory techniques are primarily concerned with the analysis of historical data. It is possible to generate characteristic curves or patterns from the data and from these patterns forecasts can be made with varying degrees of certainty. Examples of exploratory techniques are S-curves, cycles, trend extrapolation, and technology substitution.

Normative techniques start from the future by proposing a desired or possible state, and work backwards from this to determine the steps necessary to reach the required outcome. Each feasible path to the objective is analysed for its relevance and difficulty. Examples of normative techniques are relevance trees, morphological analysis, technology watch and technology monitoring, Delphi method, trend impact analysis and scenarios.

\section{Theoretical framework}

A theoretical framework of technology forecasting, suitable for Sasol's use, was formulated from the literature survey and is shown in Figure 1.

Step 1: Establish the scope. The field that technology forecasting investigates has to be very extensive if some important indications are not to be missed and it must include a wide range of social, economic, ecological and political as well as technological factors. In the energy industry, decisions tend to last a long time. A petrochemical plant has a typical lifetime of over twenty-five years. It may be necessary to make forecasts for a period of say twenty years.

Step 2: Select and coordinate resources. A multidisciplinary team or a single individual with adequate authority is needed to co-ordinate across several departments and business units. In all cases the exercise should first seek to use the knowledge and expertise of individuals within the company. Their specific knowledge of company activities and processes will be useful; much additional information can also be gleaned from their contacts and networks and from their appreciation of the general business environment. Composition of the team should be a mix of junior and senior staff, so that a variety of perspectives can be brought into the team. Technology forecasters tend to consist predominantly of scientists and engineers. Consideration should be given for bringing economists and sociologists into this discipline to have a variety of lenses through which the world can be interpreted. When confronted with a forecast that challenges the paradigms of existing business, "shooting the messenger" is often the result. Other than doing their homework and being able to substantiate their results, forecasters must also have the tenacity to propel the predictions, however sombre, through the ranks and force management to face and deal with the reality. Few companies have more than two or three full-time forecasters. Usually their involvement is confined to some part-time interested technical personnel. It is foreseeable that Sasol's forecasting team will mostly consist of part-time personnel, who have relatively wide exposure to both the technical and business environment and are passionate for the field of forecasting. Consultants and experts, whilst complementary, shouldn't replace individuals within the company. Tacit knowledge accumulated during the exercise is arguably more 
important than the final results. It is in the interest of the company to use the exercise to continuously expand its own knowledge base.

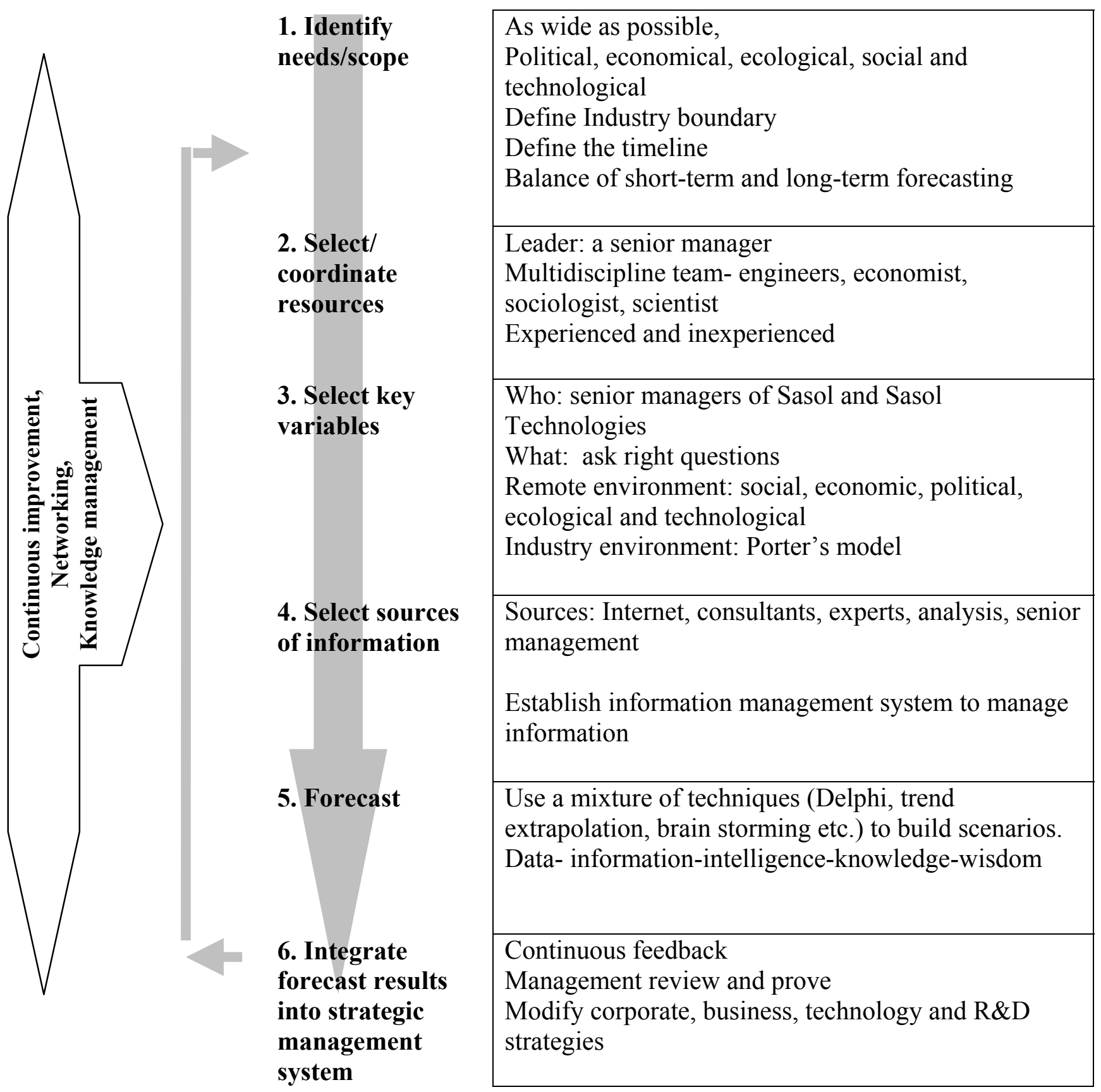

Figure 1: Theoretical Framework of Technology Forecasting.

Step 3: Select key variables. The responsibility for technology forecasting resides with top management who is in charge of technology issues. Senior managers of Sasol Technology and business units like Sasol Oil, Sasol Synfuels International, and Sasol Synthetic Fuels should be responsible to manage the process, select the key variables, and assist in obtaining the forecast data. According to Linneman and Kennell [10], key variables selected must have make-or-break consequences for the firm. Some may have been crucial in the past while some may be expected to have future importance. 
Step 4: Select sources of information. Much work has been done on the subject of energy future and there is a wide range of information sources readily available. Organizations like the US Department of Energy, World Bank, Organization of Economic Cooperation and Development, Shell, BP, Rocky Mountain Institute, the Baker Institute for Public Policy of the Rice University, Brookings Institute, to name a few, have easy-to-access Internet sites that offer in-depth analysis on energy. Most of the energy analyses, however, are limited in their scopes of investigation. In this case, additional analysts and external experts would have to be brought in to fill the gaps.

Step 5: Forecast. Ultimately, the choice of techniques is also dependent on the competency of the forecaster, availability of information, time constraint, type of results expected and relationship between the managers and forecasters involved. A combination of both quantitative and qualitative techniques could lead to a more accurate forecast. For example Shell's success of using scenarios warrants a test run on the scenario technique for the first round. Other combinations of techniques can be used to provide supporting information to further build into the overall comprehensive scenarios.

Step 6: Integrate results of technology forecasting into the strategic management process. Results of technology forecasting must ultimately be incorporated into the strategic management process. Useful forecasts should not only indicate trends of the energy industry, but also highlight opportunities and counteract threats to Sasol. The latter is of the utmost importance, as managers are able to make better-informed decisions with greater confidence, and modify the corporate strategy, business strategies of individual business units, technology strategy and R\&D strategy. Forecasters must keep close vigilance of the assumptions made that led to the initial forecasts. Should an assumption(s) later change, forecasters can timely modify the outlook, and subsequent opportunities and threats to Sasol.

\section{Critical Aspects of Managing Forecasts}

The forecasting manager should identify reputable, cost-efficient forecasting sources outside the corporation that can expand its database. In this information age, the problem is often not a lack of information but rather information overload. Forecasting involves the skill to process information into a relevant, digestible, intelligent, analytical and insightful format that can be used in decision-making. Knowledge needs to be captured, stored, retrieved, distributed and managed within the company. A potential challenge is to try to avoid immersing oneself too deeply into the topic or becoming distracted by many other tangential subjects and so digress from the original objectives. Investment and resources spent on forecasting can only be justified in terms of the benefit expected to be derived from it. Expenditure or time spent on forecasting which does not aid decision-making must be minimized. As Drucker [11] points out, "The question that the long-range planner faces is not what we should do tomorrow, it is: What do we have to do today to be ready for an uncertain tomorrow? The question is not what will happen in the future...[But] how do we converge them to a simultaneous decision in the present?" 


\section{RESEARCH METHODOLOGY}

Interviews were conducted with a number of key personnel in Sasol, such as technology managers, strategy facilitators and technology trackers, to gather data and information on how technology forecasting was conducted as well as the relationship between technology forecasting and strategic management process. The information obtained during the interviews was compared with the theoretical framework of technology forecasting to establish whether an appropriate technology forecasting process exists in Sasol.

\section{History and Culture of Sasol}

The construction of Sasol's first synthetic fuel plant started in 1951 and by 1955 this operation started marketing petrol. It would, however, be 1960 before the plant was running at reasonable reliability. Sasol One was believed then to be the most difficult plant in the world to operate. The hardship that Sasol's staff endured in constructing and commissioning Sasol One, taught Sasol from very early on to develop an in-house technology portfolio and R\&D capabilities instead of relying on overseas vendors. Sasol is in constant need of new ideas to solve problems and find new opportunities due to its unique process in the world. Unusual, even eccentric ideas are tolerated, but the initiator must do the homework, lobby the management and gain support. Sasol's managers demand results but give subordinates sufficient freedom to figure out how to achieve them.

Sasol's expertise in project management and execution, research and development, and commercialisation of new technologies are regarded as world class by peers. However, as Sasol grows bigger and becomes more complex, specialists become increasingly so focused in their own production areas that they tend to lose sight of the bigger picture. Sasol has been very comfortable and business has been good. Supply agreements with other South African oil companies has guaranteed Sasol's access to the markets. Any fuel produced is sold. The danger is that complacency can set in and people drift towards ignorance of what is happening in the rest of the industry.

\section{Sasol's Strategic Management Process}

There isn't a single, homogeneous corporate strategic management system in Sasol. "The Group Executive Committee (GEC) gives each business unit a direction statement, you can put all direction statements onto one page", Dr Vosloo, the strategy coordinator explains, "How each business unit devises its strategy to meet these objectives, however, is left to the business units themselves to decide." The result is a highly complex strategic management system. About five years ago, Sasol initiated globalisation and attempted to market its Gasto-Liquids technology to the world market. To facilitate learning of the global business environment, Sasol Strategy Team (SST) was formed to develop a new corporate strategic management process. Scenario planning was chosen by SST as a tool to consolidate existing strategic management processes, and is incorporated into the corporate strategic management process. Business strategies developed by the business units would be checked against the scenarios for "robustness". 


\section{Technology Forecasting in Sasol}

Technology forecasting efforts within Sasol appears to be rather fragmented and is scattered within the company.

The R\&D department has an Emerging Technology Forum (ETF), which monitors technologies that may have significant impact on Sasol. Being part of the R\&D initiative, ETF has a long-term focus. But ETF fails to incorporate its findings of emerging technologies with other external environmental factors to produce a picture of what the future may look like, and how Sasol could be affected. ETF limits its function largely to collecting information; and no in-depth analysis and forecasting are conducted.

The Fuel Strategy Platform (FSP) is dedicated to formulating a new technology strategy for Sasol's fuel business. The old energy strategy was aimed at meeting market needs, and future related research was very limited. The purpose of FSP is to develop a technology strategy that enables Sasol to take a more proactive approach to meet the market demand and identify new opportunities and threats. Firstly they identified the most crucial technologies that FSP should study. The study involved about a hundred people and took nearly two years to complete. Apparently no formal technology forecasting techniques were used. The second part was to consolidate the information and integrate it into a strategy. The team assimilated the information, through extensive discussion and largely by intuition and a technology strategy slowly emerged. Murray, the facilitator commented that this proved to be a difficult process. FSP is now at the phase to integrate its technology strategy with the business strategies of the business units.

FSP aims at identifying the key technologies that might impact on Sasol, and involves people at all levels in the organization. FSP attempts to conduct some form of technology forecasting, but it remains in a preliminary stage. The 'Champion' of each technology has written technology briefs, outlining the technology and potential impacts on Sasol. A typical technology brief consists of the description, benefits, status, barriers to further development, competing technologies, potential applications of the technology, potential commercial acceptance and potential impact of the technology. A technology brief gives a fairly good overview of the specific technology. However, the information is basic, from which it is difficult for managers to make strategic decisions.

FSP has been quite an achievement considering the large number of people involved and long period of time taken. FSP consolidates all the information and reaches consensus on the new fuel technology strategy largely by intuition and no particular forecasting techniques were used. The biggest benefit of this exercise, however, is to stretch the participants' thinking. FSP is successful in the sense that it expands people's minds, encourages networking and knowledge sharing not only within the company but also outside the company. Instead of meeting the market requirement reactively, the new fuel strategy has a distinctive forwardlooking flavour. 


\section{CONCLUSIONS}

The key conclusions and recommendations of this study are the following:

- Technology forecasting in Sasol is currently limited to the monitoring of specific technologies. As the output from such exercises has a relatively short-term view, it does not require sophisticated techniques. The lack of in-depth analyses and unsophisticated techniques limits the contributions that technology forecasting could have made to the company. The lack of long-term analysis for the energy industry, between fifteen and twenty years ahead, must be addressed.

- Technology forecasting in Sasol appears to be dominated by scientists and researchers in R\&D. Technology forecasting of the energy industry, however is too important and complex to be done by R\&D alone.

- In theory, technology forecasting should be carried out at the corporate level. Technology forecasting is currently limited to the department and business unit levels. The complexity of Sasol's business structure may justify some business units to conduct their own technology forecasting for their specific requirements. However, a senior manager from the corporate level should manage and coordinate the process.

- Technology forecasting requires the involvement of people from various departments and companies, in order to facilitate communication and networking. Forecasting compels people to think systematically and expand their perspectives, thereby help transform Sasol into the proactive and progressive 'Learning Organization' it purports to be. This could be the most valuable outcome that the forecasting manager can expect to produce.

- There is a strong awareness within the company of the importance of knowing in which direction the future is tending towards and substantial effort and resources are being committed to this endeavour. What is needed is a more systematic approach towards technology forecasting. Hence the proposed theoretical framework presented in this report could be implemented as a means to facilitate the process.

- While the theoretical model of "what" has to be done was presented in Figure 1, some thought should be given to the "mechanism" in the corporation that would do this. The underlying assumption is that this is an ongoing management process, but the structure and process to do this must be a development goal for the organisation. Such a mechanism (structure plus process) must allow the integration of the insights at the operational/technical level with those of the strategic level. The strategic context provided by the strategic analysis of the variables in the remote and industry environments has to be formalised to guide the information gathering at the divisional and operational levels. Similarly the insights developed at these levels should influence the strategic scenarios by the awareness of technological trends arising at the "technical" level. Overall the mechanism is the means to conduct a continuous, formal "conversation" up and down the (corporate) management hierarchy to come to a coherent strategic insight about the future and the possible ways and means to deal with the implications of this insight.

\section{REFERENCES}

[1] Adelman M.A., 1995, "The Genie out of the Bottle", Cambridge, Massachusetts, MIT Press, pp.15-17.

[2] "Saudi Dove in Oil Slick", 2001, The Observer, 14 January 2001. 
[3] Pearce J.A. and Robinson Jr. R.B., 1994, "Strategic Management, Formulation, Implementation and Control", Seventh Edition, McGraw-Hill, p 63.

[4] Twiss B.C., 1980, "Managing Technological Innovation", New York: Long Man, pp. 206-234.

[5] Porter M.E., 1979, "How Competitive Forces Shape Strategy", Harvard Business Review, March-April 1994, pp. 137-145.

[6] Porter M.E., 1983, "Research on Technological Innovation", Management and Policy, Vol. 1, JAL Press, Inc.

[7] De Geus A., 1997, "The Living Company", Harvard Business School Press.

[8] Brenneman W.B., Keys J.B. \& Fulmer R.M., 1998, "Learning across a living company: the Shell Companies' experiences", Organizational Dynamics, Autumn 98, Vol.27 Issue 2, p61.

[9] Tidd J., Bessant J. \& Pavitt K., 2001, "Managing Innovation", John Wiley \& Sons.

[10] Linneman R.E. \& Kennell J.D., 1997, "Shirt-Sleeve Approach to Long-Range Plans", Harvard Business Review, March-April 1997, p. 145.

[11] Drucker P.F., 1970, "Technology, Management, and Society", Heinemann. 
